\title{
ACTIVITY bUdGETS AND distribution OF bOTTLENOSE dOLPHINS (TURSIOPS TRUNCATUS) in the Patos Lagoon estuary, southern Brazil
}

\author{
Paulo H. Mattos ${ }^{1}$, Luciano Dalla Rosa ${ }^{1,2}$ and Pedro F. Fruet ${ }^{1}$
}

\begin{abstract}
The common bottlenose dolphin, Tursiops truncatus, is one of the world's best known cetaceans. However, there are few studies on the activity budgets and distribution of this species along the Brazilian coast. This study aimed at describing and quantifying the behavioral activity of T. truncatus in the Patos Lagoon Estuary, Rio Grande do Sul state, southern Brazil (ca. $\left.32^{\circ} 09^{\prime} \mathrm{S}, 52^{\circ} 05^{\prime} \mathrm{W}\right)$. The study area was divided into three sub-areas according to the proximity to the estuary mouth. The behavioral data were gathered every 5 minutes following a focal group sampling approach. A total of 34 boat surveys were conducted between December 2001 and January 2003, totaling 66.95h of direct observation and 672 records of behavioral activities. The first 15 minutes of each group encounter were discarded to avoid the influence of the boat approach on dolphin behavior. The most observed behavior was feeding (37.64\%), followed by traveling (29.17\%), travel-feeding (21.87\%), socializing (5.8\%), milling $(4.33 \%)$ and resting $(1.19 \%)$. There was not a significant difference among the frequencies of commonly observed behaviors: feeding, traveling and travel feeding ( $p>0.05$, t-test for proportions). Dependence between activity and season was detected in subareas I and II $\left(\mathrm{p}<0.001\right.$; Pearson's $\left.X^{2}\right)$, as well as an association between activity and sub-areas ( $\mathrm{p}<0.001$; Pearson's $\left.X^{2}\right)$. Regarding group size, $56.41 \%$ of the activities recorded were carried out by groups of 1 to 3 dolphins, 31.63\% from 4 to 6 , $10.25 \%$ from 7 to 10 , and $1.71 \%$ by groups with more than 10 individuals. This study confirmed the importance of the Patos Lagoon Estuary as an area for bottlenose dolphins to conduct their daytime activities, in particular feeding.
\end{abstract}

Resumo: O boto ou golfinho nariz-de-garrafa, Tursiops truncatus, é um dos cetáceos mais bem conhecidos no mundo. Entretanto, existem poucos estudos sobre a atividade comportamental e distribuição desta espécie ao longo da costa brasileira. O objetivo deste trabalho foi descrever e quantificar os comportamentos de T. truncatus no Estuário da Lagoa dos Patos, Rio Grande do Sul, Brasil $\left(32^{\circ} 09^{\prime} \mathrm{S}, 52^{\circ} 05^{\prime} \mathrm{W}\right)$. A área de estudo foi dividida em três subáreas de acordo com a proximidade da desembocadura do estuário. Os dados comportamentais foram registrados a cada 5 minutos seguindo a metodologia de amostragem de grupo focal. Um total de 34 saídas foram conduzidas entre dezembro de 2001 e janeiro de 2003, totalizando 66,95h de observações diretas e 672 registros de atividades comportamentais. Os primeiros 15 minutos de cada grupo encontrado foram descartados a fim de evitar qualquer influência da aproximação da embarcação no comportamento dos animais. O comportamento mais observado foi alimentação (37,64\%), seguido por deslocamento $(29,17 \%)$, deslocamento com alimentação $(21,87 \%)$, socialização $(5,8 \%)$, milling $(4,33 \%)$ e descanso $(1,19 \%)$. Não houve diferença significativa entre as freqüências de comportamento mais comuns: alimentação, deslocamento e deslocamento com alimentação ( $p>0.05$, teste $t$ para proporções). Detectou-se uma dependência entre o tipo de atividade e a estação do ano nas subáreas I e II ( $\mathrm{p}<0,001$, Pearson's $\left.X^{2}\right)$, assim como uma associação entre o tipo de comportamento e a subárea $\left(\mathrm{p}<0,001\right.$, Pearson's $\left.X^{2}\right)$. Com respeito ao tamanho do grupo, 56,41\% das atividades registradas foram realizadas por grupos de 1 a 3 indivíduos, 31,63\% de 4 a 6 , 10,25\% de 7 a 10 e apenas 1,71\% por grupos com mais de 10 indivíduos. Este estudo confirma a importância do Estuário da Lagoa dos Patos como área para os botos executarem suas atividades diurnas, em especial a alimentação.

Keywords: common bottlenose dolphin, Tursiops truncatus, activity budget, behavioral ecology, distribution, group size, Brazil.

\section{Introduction}

The common bottlenose dolphin (Tursiops truncatus) is found in temperate and tropical waters worldwide. The species is common in pelagic as well as coastal waters, where they are often found in bays and tidal creeks, and are even known to travel up rivers (Leatherwood et al., 1983a; Rice, 1998; Cubero-Pardo, 2007). The existence of several nearshore populations and some long-term studies has made $T$. truncatus one of the best known cetaceans, with described coastal and offshore forms or ecotypes (Leatherwood et al., 1983a; Segura et al., 2006) which differ in physiology, morphology, and ecology (Duffield et al., 1983; Hersh and Duffield, 1990; Mead and Potter, 1990).

In Brazilian waters, the common bottlenose dolphin has been reported from the northeastern (Alves Júnior et al., 1996) to the southern (Simões-Lopes, 1991; Castello and
Pinedo, 1977) coasts. In the state of Rio Grande do Sul, southern Brazil, bottlenose dolphins are commonly found in coastal waters, forming small populations or subpopulations associated with river and estuary mouths (Möller et al., 1994). However, there have been few studies on their behavior along the Brazilian coast (Pryor and Lindbergh, 1990; Möller, 1993). Bottlenose dolphins in the Patos Lagoon estuary, southern Brazil, form a small and resident population estimated at 83 dolphins (95\% CI: 72-90; Dalla Rosa, 1999). A previous study on the behavioral activities of this population showed that dolphins used the area for all activities, especially feeding, and usually concentrated near the estuary mouth in small groups of up to 5 individuals (Möller, 1993).

The opportunistic feeding habits of $T$. truncatus are demonstrated by its use of various foraging strategies (Shane, 1990). Bottlenose dolphins feed upon a wide

\footnotetext{
${ }^{1}$ Museu Oceanográfico Prof. “Eliézer C. Rios”, Fundação Universidade Federal do Rio Grande, Rio Grande, RS, 96200-970, Brazil. E-mail: biofurg@yahoo.com.br.

${ }^{2}$ Department of Zoology and Marine Mammal Research Unit, Fisheries Centre, University of British Columbia, Room 247, AERL, 2202 Main Mall, Vancouver, B.C. V6T 1Z4, Canada.
} 
variety of fish, including small rays and sharks, as well as cephalopods (squid and octopus), and occasionally shrimp (Leatherwood, 1975; Barros and Odell, 1990; Mead and Potter, 1990; Cockcroft and Ross, 1990). Whereas this wide range of feeding habits has led, along with social interactions, to the documentation of several types of behavioral events, their activity budgets are generally described in terms of four major categories: feeding, traveling, socializing and resting (Shane et al., 1986). Studies on behavioral ecology lead to a better understanding of habitat use and of the potential impacts of habitat degradation and incidental mortality. This is particularly important for the management of small coastal populations of cetaceans. In this paper, we present new information on activity budgets and distribution of bottlenose dolphins in the Patos Lagoon estuary.

\section{Material and Methods}

The Patos Lagoon estuary ( $31^{\circ} 50^{\prime} \mathrm{S}, 5^{\circ} 20^{\prime} \mathrm{W}$; Figure 1 ) is a nursery area for several commercially important species of fish from this region, including Micropogonias furnieri, Cynoscion guatucupa, Paralonchurus brasiliensis

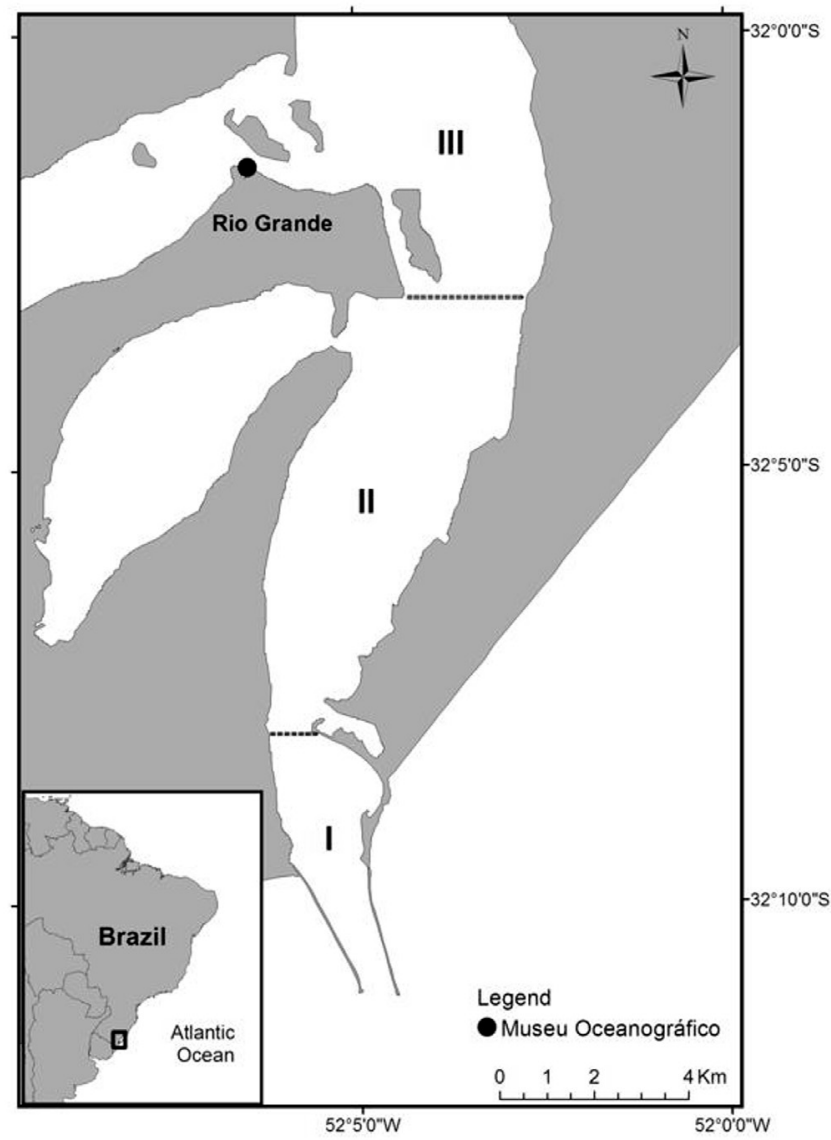

Figure 1. Map of the study area in the Patos Lagoon estuary. Roman numbers indicate the three sub-areas. and Menticirrhus americanus (Chao et al., 1985; Vieira and Scalabrin, 1991; Vieira, 2006). Located along the coastal plain of Rio Grande do Sul state, in southern Brazil, Patos Lagoon is the largest choked lagoon in the world (Kjerfve, 1986) and is characterized by industrial and artisanal fisheries, tourism, port activities and oil refinery, fertilizer and fish processing plants (Tagliani et al., 2003). The Patos Lagoon is connected to the Atlantic Ocean through a narrow channel $(0.5-3 \mathrm{~km})$, which is secured by two rock-jetties at the estuary mouth (Seeliger et al., 1997). Marine water influx at this mouth can reach $1.3 \mathrm{~m} \mathrm{~s}^{-1}$, and freshwater discharge after long periods of rain can result in currents of up to $1.7-1.9 \mathrm{~m} \mathrm{~s}$ ${ }^{1}$ (DNPVN, 1941) ${ }^{3}$. The marine water intrusion is favored during periods with higher temperatures, lower precipitation and southwesterly winds, leading to higher salinity values in the estuary. Increased freshwater runoff and lower salinity values are observed during periods of high precipitation or prevailing northeasterly winds (e.g. Möller and Castaing, 1999). Mean water temperature ranges from about $25^{\circ} \mathrm{C}$ in January (warmest month) to $12^{\circ} \mathrm{C}$ in July (coldest month) (Laboratório de Tartarugas e Mamíferos Marinhos-FURG, unpublished data).

The study area was divided into three sub-areas according to the proximity to the mouth of the estuary, being sub-area I closest and sub-area III more distant from the entrance. Sub-area I comprises approximately $10 \mathrm{~km}^{2}$, sub-area II $20 \mathrm{~km}^{2}$ and sub-area III about $10 \mathrm{~km}^{2}$ (Figure 1). On occasion surveys extended to the adjacent coastal waters up to about $3 \mathrm{~km}$ north and south of the estuary mouth.

Thirty-four boat surveys were conducted from December 2001 to January 2003. We used a 5.5m aluminum boat with a 50hp outboard engine. The survey design followed a zig-zag transect from north to south along the study area to increase the chance of encountering dolphin groups. Behavioral data were collected following the Focal Group Sampling approach (Altmann, 1974), in which the behavior of a focal group, characterized by the presence of at least one animal with identifiable natural markings, was recorded every 5 minutes. Approximately $51.5 \%$ of the individuals of the Patos Lagoon population show conspicuous long-lasting marks (Dalla Rosa, 1999) facilitating the use of this methodology.

A group was defined as any number of dolphins observed in apparent association, moving in the same direction, within $30 \mathrm{~m}$ of any individual in the group and often, but not always, engaged in the same activity (see Shane, 1990). When a group was sighted, we slowly approached the group to minimize disturbance and recorded the time, sub-area, group size and geographic position using a hand-held GPS.

${ }^{3}$ DNPVN (1941) Enchentes de maio de 1941. Diretoria Nacional de Portos e Vias de Navegação. Relatório Técnico, Porto Alegre. 
Four major behavioral categories were considered in this study: feeding, traveling, socializing and resting (Shane, 1990). Feeding was characterized by the lack of directional movement. The animals generally surfaced and dove asynchronously while the entire group remained loosely aggregated over an area of several meters. Traveling was characterized by directional movement of a group, moving as a unit. Resting was characterized by low levels of activity during which almost no forward movement of the animals occurred. A resting animal slowly rose to the surface with its head and dorsal fin breaking the water simultaneously. Socializing animals surfaced together in a tight aggregation and often remained at or near the surface for several minutes. During this time, animals exhibited prolonged body contact, often in the form of slaps of the flukes or pectoral fins of one animal against the body of another.

Two additional categories included activities that did not fit well into the behaviors described above: milling and travel-feeding. Milling involved frequent changes in heading with movements generally lacking components of the other types of behavior (Shane, 1990). An association of traveling with feeding, travel-feeding was characterized by animals moving consistently in one direction while foraging and feeding regularly. Although this category could potentially be considered just feeding, we deemed that its frequency of occurrence and distinctive characteristics warranted a separate classification (e.g. Bearzi, 2005).

The first 15 minutes of each group encounter were discarded to avoid the influence of the boat approach on dolphin behavior. Observation periods were divided into three periods: 09:00-12:00h; 12:01-15:00h and 15:0118:00h. Encounter rates of groups per hour of searching effort were calculated in order to adjust for unequal effort in the sub-areas, allowing us to verify area use by season and by time of the day.

The Pearson's X² test (Zar, 1984) was used to investigate associations among the type of behavior, season and sub-area. The t-test for difference of proportions (Zar, 1984) was used to verify if the frequencies of the observed behavioral categories were significantly different. All tests were performed using a $5 \%$ level of significance.

\section{Results}

Activity budgets

A total of 672 behavioral records were obtained during $66.95 \mathrm{~h}$ of direct observation of dolphin groups. Feeding was the most frequently observed activity $(37.64 \%)$, followed by traveling $(29.17 \%)$, travelfeeding $(21.87 \%)$, socializing $(5.8 \%)$, milling $(4.33 \%)$ and resting $(1.19 \%)$. There was no significant difference between feeding, traveling and travel-feeding frequencies (t-test for proportions, $\mathrm{p}>0.05$ ).

An association was observed between the activity and the sub-areas $\left(\mathrm{p}<0.001 ;\right.$ Pearson's $\left.X^{2}\right)$. All behavioral categories were observed in sub-area I, where feeding was the most frequent, followed by traveling ( $n=551$; Figure 2). Greater total effort was spent in sub-area I than in sub-areas II and III, partly as a consequence of higher encounters rates in this area (see Table 1). Only 101 behavioral observations were recorded in sub-area II, where travel-feeding was the most frequent activity (36.63\%). The number of observations in sub-area III was too small to be statistically analyzed (Figure 2).

An association between activity and season was detected in sub-areas I and II $\left(p<0.001\right.$; Pearson's $\left.X^{2}\right)$. All behavioral categories were observed during summer, when feeding and traveling were the most frequent activities ( $n=218$; Figure 3). During fall, travel-feeding was the most frequently observed activity, whereas resting was not observed. Winter was the season with the highest relative frequency of feeding, followed by traveling and travel-feeding $(n=124 ;$ Figure 3$)$. Traveling was the most frequent activity in spring, followed by feeding (Figure 3). There was no significant difference between traveling and socializing during this season $(t$ test for proportions, $\mathrm{p}>0.05$; Figure 3 ).

Regarding the distribution of activities according to the daytime periods, most observations were made in the morning (09:00-12:00h; $\mathrm{n}=304)$, probably due to increased survey effort. Feeding was the most frequent activity during this period (Figure 4).

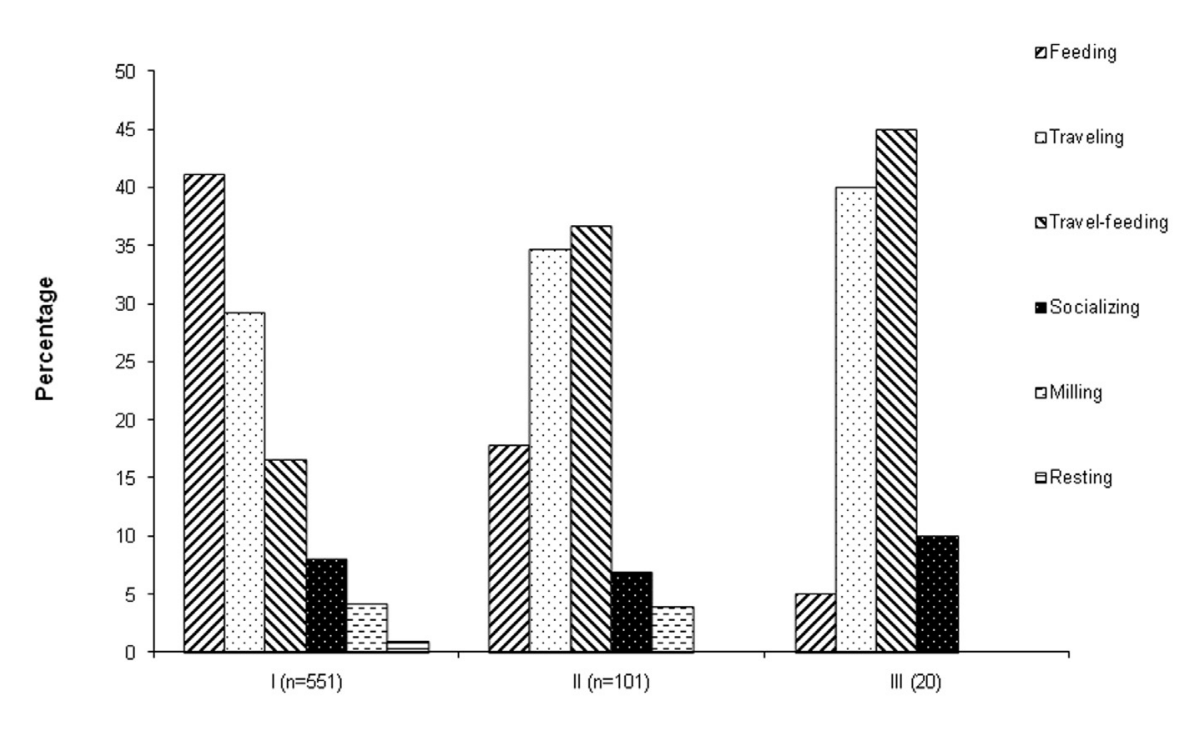

Sub - Area

Figure 2. Activity budgets of bottlenose dolphins in the Patos Lagoon estuary, by sub-area. 
Table 1. Encounter rates (groups per hour) of bottlenose dolphins in the Patos Lagoon estuary by sub-area, season and daytime period.

\begin{tabular}{lccc}
\hline \hline SUB-AREA & GROUPS & EFFORT $(\mathrm{h})$ & ENCOUNTER RATE \\
\hline \hline I & 102 & 29.02 & 3.51 \\
II & 11 & 26.01 & 0.42 \\
III & 4 & 11.54 & 0.34 \\
\hline Season & & & \\
\hline Summer & 35 & 16.04 & 2.18 \\
Fall & 34 & 11.47 & 2.96 \\
Winter & 23 & 13.38 & 1.72 \\
Spring & 25 & 25.68 & 0.97 \\
\hline Daytime & & & \\
\hline 09:00-12:00h & 59 & 41.16 & 1.43 \\
12:01-15:00h & 40 & 19.21 & 2.08 \\
15:01-18:00h & 18 & 6.20 & 2.90 \\
\hline \hline
\end{tabular}

Effort refers to searching effort only.

During the 12:01-15:00h period, we observed an increase in both feeding and travel-feeding relative to the other periods ( $\mathrm{n}=210$; Figure 4$)$. Feeding and traveling were the most frequent activity observed between 15:01h and 18:00h (n=158; Figure 4).

\section{Distribution and Group Size}

Bottlenose dolphins were present in the study area in all but one of the 34 surveys. A total of 117 groups were recorded between the Porto Novo of the city of Rio Grande and the mouth of the estuary, including adjacent areas. Most sightings occurred in sub-area I (Table 1; Figure 5).

The average group size was 4.05 dolphins $(S D=2.10)$. Group size frequencies were $25.63 \%$ for pairs, $20.66 \%$ for trios, $30.58 \%$ for groups of 4 to 6 , $9.91 \%$ for 7 to 10 , and $2.48 \%$ for larger groups. Lone individuals accounted for $10.74 \%$ of the sightings. Groups larger than 4 individuals were the most common in sub-area I $(29 \%)$, followed by pairs and trios $(20.9 \%$ each), while pairs and trios were most common in sub-areas II and III, respectively. Larger groups ( $>4$ ) were also the most common during spring and summer (44 and 37.14\%, respectively). Pairs predominated during fall $(33.3 \%)$ and trios during winter $(36.3 \%)$.

\section{Discussion}

Several techniques are available for recording animal behavior. Mann
(1999) presents a review on behavioral sampling methods for cetaceans and points out the potential biases of each method. According to this author, the focal-group sampling is not recommended because it tends to bias towards most common or conspicuous behaviors, therefore overestimating their relative importance in a group. Also, the focal-group methodology (Altman, 1974) was proposed for groups in which all individuals were continuously visible through the sampling period, and when these conditions were not met, this method should only be applied for individuals or pairs. Keeping in mind these limitations, we still chose to use this approach for several reasons. Groups, as we defined them, tend to be relatively small in our study area and engage in the same activity, minimizing the potential biases mentioned above. In addition, alternative methods also present difficulties. In particular, individuals that are visually identifiable from natural markings within a reasonable distance tend to be older and possibly males (e.g. Wilson, 1995); therefore using an individualfollow protocol would bias sampling towards this age and sex classes. Difficulties in distinguishing among unmarked animals would also potentially bias sampling methods such as scan sampling (Mann, 1999), where individuals should be sampled sequentially. And finally, for comparative purposes, we preferred to use the same method used in a previous study in the same area (see Möller, 1993). Once sampling was concluded, we compared the behavioral frequencies between groups of 1-2 individuals and groups of 3 or more individuals to verify if there was any evidence that the most common activities could have been overestimated in the larger groups, as suggested above. However, feeding actually decreased in larger groups, traveling and travel-feeding frequencies were similar and socializing and milling increased, suggesting that this type of bias was likely not important.

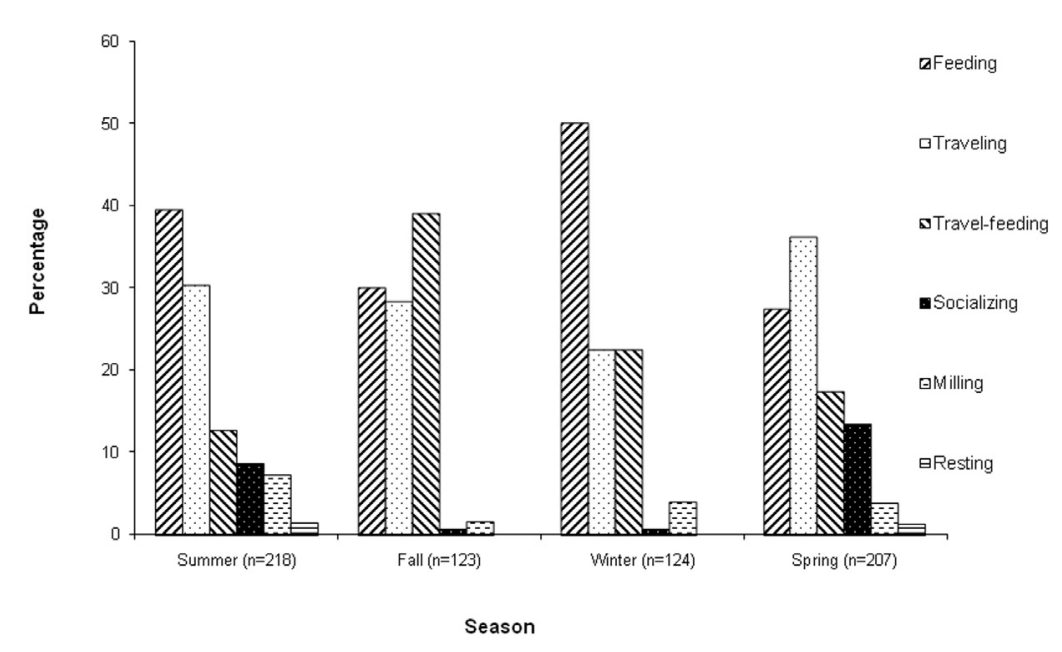

Figure 3. Activity budgets of bottlenose dolphins in the Patos Lagoon estuary, by season. 
Feeding was the most common activity recorded in sub-area I. Möller (1993) also observed a higher amount of feeding in this sub-area, although with a lower relative frequency which was similar to socializing. This is not surprising because subarea I comprises a narrow and steep channel with fast currents at the estuary mouth. Bottlenose dolphins seem to prefer narrow channels and features such as steep slopes, uneven bottom substrates and tidal eddies, which are known to attract or concentrate fish (Wilson et al., 1997). By functioning as a bottleneck for fish moving through this kind of habitat, these features may help dolphins to take advantage of prey concentration, improving their foraging efficiency (Hastie et al., 2004). The rocky formation of the jetties in sub-area I may also attract fish that commonly associate with rocks. Information on prey distribution and biomass would certainly improve our understanding of the behavior and distribution of bottlenose dolphins in the study area, and should therefore be pursued in future studies.

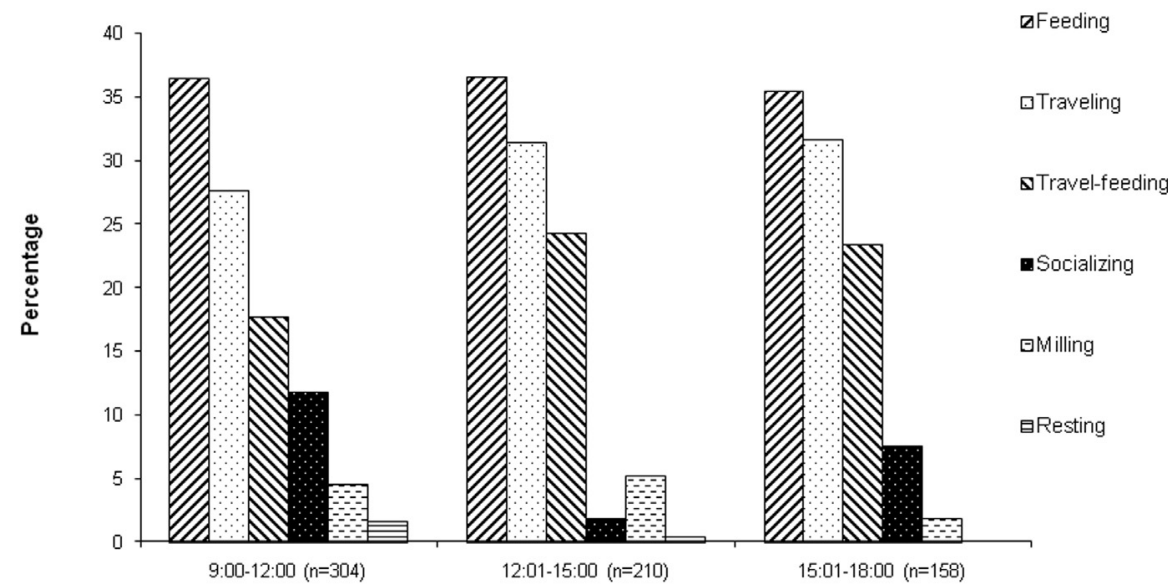

Figure 4. Activity budgets of bottlenose dolphins in the Patos Lagoon estuary, by daytime period.
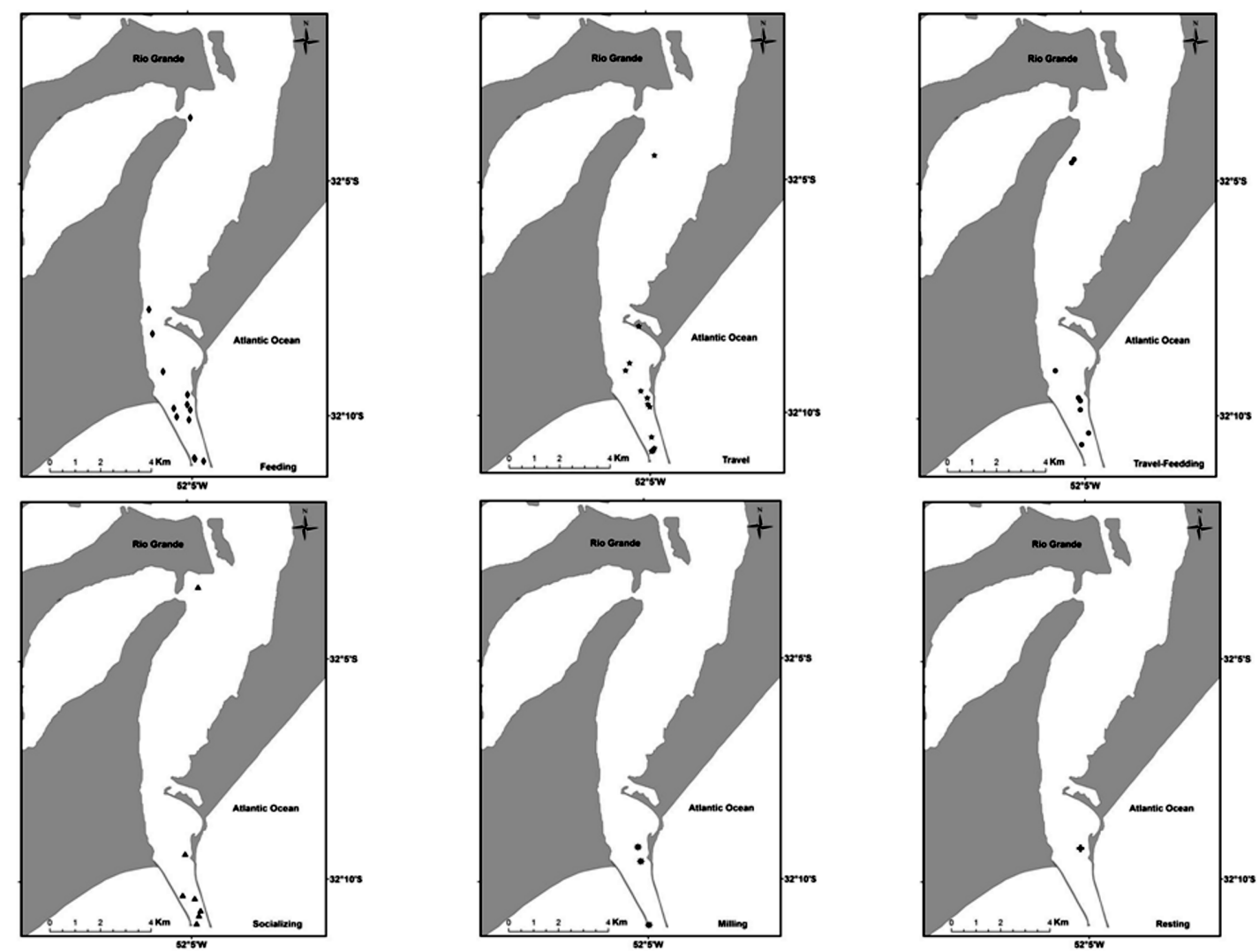

Figure 5. Distribution of the first activity recorded for each bottlenose dolphin group along the study area. Note that sampling of behavioral activities was not possible for all recorded dolphin groups. 
Activity budgets also changed seasonally in sub-areas I and II. The higher relative frequency of feeding in winter, which was also observed by Möller (1993), and the predominance of travel-feeding in fall might be related to increased energy requirements in cold waters (Shane, 1990), lower prey densities in the study area or a change in diet. Pinedo (1982) reported a great amount of Sciaenidae fish in the stomach contents of bottlenose dolphins stranded along the coast near the Patos Lagoon estuary. The white croaker, Micropogonias furnieri, accounted for nearly $80 \%$ of the absolute frequency of prey in the stomachs (Pinedo, 1982). However, the sample size was small and did not represent all seasons. Therefore, no conclusions can be drawn regarding seasonal variation in feeding preferences of this population and how it might affect their activities. From observations on surface feeding behavior, it is suggested that the cutless fish, Trichiurus lepturus, and the mullet, Mugil platanus, may also be important seasonal prey species. The Patos Lagoon estuary is a highly seasonal environment, with fish abundance and assemblage changing across the seasons (Ramos and Vieira, 2001). Specifically, fish abundance decreases drastically during the cold months, which could force the dolphins to spend more time feeding and foraging (e.g. Bearzi et al., 1999). The highest frequency of socializing observed in the spring is likely due to an increase in the frequency of mating interactions. Considering that the gestation period in this species is approximately 10 to 12 months long (Wells et al., 1987), this would explain the highest incidence of calves in the study area at the end of the spring and beginning of the summer (Fruet, 2008). Möller (1993) did not conduct surveys in spring; however socializing was the most frequently observed activity in the summer in her study. The few records of resting in our study were made in the spring and summer months, in contrast with the previous study, where resting was more frequent in the fall. However, the low number of resting observations should not be interpreted as an indication that this activity was not important in the study area. Given that our observation periods were limited to daylight hours, resting could be underestimated. Experiments with bottlenose dolphins in captivity suggest that resting at the surface may occupy between 50 and $70 \%$ of the nighttime in adults (Lyamin et al., 2007), and telemetry data also indicate that wild bottlenose dolphins might engage in this activity predominantly at night (Mate et al., 1995).

Differences in activity budgets over the course of the day were not as marked as seasonal and spatial differences, at least for the most commonly observed activities. Feeding frequencies were relatively constant throughout the day, while Möller (1993) found a steady increase in feeding over the course of the day. Bottlenose dolphins in South Africa (Tayler and Saayman, 1972; Saayman et al., 1973) and Texas (Shane, 1977; Shane et al., 1986) fed more frequently in the early morning and late afternoon, possibly in response to the diurnal patterns of prey. We observed a slight increase in traveling and especially travel-feeding in the early afternoon, with similar frequencies remaining in the late afternoon. Möller (1993) also observed a higher frequency of traveling in the beginning of the afternoon. Resting was more frequent in the morning, and it was not observed in the evening. Möller (1993) reported resting during the three periods, with a higher frequency in the morning, and bottlenose dolphins in Argentina also rested in the morning (Würsig and Würsig, 1979).

During the present study, bottlenose dolphins were found all over the study area; however a preference for the region between the jetties in sub-area I was observed (Fig.5), similarly to previous studies in the area (Möller, 1993; L. Dalla Rosa, unpublished data). Common bottlenose dolphins tend to aggregate inside or near the entrances to estuaries, lagoons and bays (Leatherwood and Reeves, 1983b; dos Santos and Lacerda, 1987; Ballance, 1992; Fertl, 1994; Wilson et al., 1997; Cortese, 2000; Garrison and Yeung, 2001; Read et al., 2003), often concentrating in areas of fast tidal current (Irvine et al., 1981; Shane, 1980, 1990; Harzen, 1998). Therefore, lower encounter rates in sub-areas II and III were expected. We suspect, however, that they were lower than usual. The 2002/03 warm El Niño event (McPhaden, 2004) that occurred during this study resulted in higher precipitation indices in the Patos Lagoon and salinity values below the average of the previous thirteen years (Laboratório de Ictiologia/Fundação Universidade Federal do Rio Grande, unpublished data). Salinity values in the Patos Lagoon estuary vary according to precipitation and wind-driven circulation (e.g. Calliari, 1980; Costa et al., 1988), affecting the abundance and distribution of marine fish species (Garcia et al., 2001) that are prey for the bottlenose dolphins. High salinity values in the inner portions of the estuary lead to increased marine fish abundance and thus have the potential to attract foraging dolphin groups further into the estuary. We assume low salinity values and decreased fish abundance would have the opposite effect, particularly in sub-areas II and III.

We must point out that we investigated the distribution of bottlenose dolphins only near the mouth of the Patos Lagoon estuary. As they also travel along the coastline, in both southward and northward directions, it would be important to carry out a larger-scale study to investigate the home range and core areas of this population.

The structure and composition of dolphin groups is based on the age, gender, kinship and reproductive condition of the individuals (Wells, 1991; Krützen et al., 2003; Parsons et al., 2003; Möller, 2006). Group size and composition in bottlenose dolphins varies among different populations. In the west coast of Florida, the average group size is about 10 animals (Scott and Chivers, 1990), while in California group sizes of about 18 (Hansen, 1990) and 9 (Bearzi, 2005) individuals have 
been reported. In the present study, the average group size was very similar to that reported by Dalla Rosa (1999) for the same area (4.44 individuals) and by Campbell et al. (2002) for a Central American population, where 3.8 individuals were recorded. Flores and Fontoura (2007) reported a group size of 5.4 individuals in Baía Norte, Santa Catarina State, Brazil, for this species.

In conclusion, this study confirms the importance of the Patos Lagoon estuary for the population of bottlenose dolphins and demonstrates that the area next to the mouth of the estuary is highly used by the dolphins during the daytime and throughout the year, providing the necessary conditions for the accomplishment of vital activities such as feeding, socializing and resting.

\section{Acknowledgements}

We wish to thank Lauro Barcellos and the staff of the Museu Oceanográfico "Prof. Eliézer C. Rios" for the logistical support. Special thanks to Altemir Brás Pinto for driving the boat during all surveys and Juliana Di Tullio for technical support. Two anonymous reviewers made helpful comments and suggestions that greatly improved the manuscript. This work was supported by Companhia Brasileira de Projetos e Obras (CBPO) and Fundo Nacional do Meio Ambiente (FNMA).

\section{References}

Altmann, J. (1974) Observational study of behaviour: sampling methods. Behaviour 49: 227-267.

Alves Júnior, T.T., Ávila, F.J.C., de Oliveira, J.A., Furtado Neto, M.A.A. And Monteiro Neto, C. (1996) Registros de cetáceos para o litoral do estado do Ceará, Brasil. Arquivo de Ciências do Mar, Fortaleza, 30(1-2): 70-83.

BAILEY, H. AND THOMPSON, P. (2006) Quantitative analysis of bottlenose dolphin movement patterns and their relationship with foraging. Journal of Animal Ecology 75: 456-465.

BALLANCE, L.T. (1990) Residence patterns, group organization, and surfacing associations of bottlenose dolphins in Kino Bay, Gulf of California, Mexico. Pages 267-283 in LeATHERWOOD, S. and Reeves, R.R. (Eds) The Bottlenose Dolphin. San Diego, California, Academic Press, Inc.

Ballance, L.T. (1992) Habitat use patterns and ranges of the bottlenose dolphin in the Gulf of California, Mexico. Marine Mammal Science 8(3): 262-274.

BARROS, N.B. AND ODELL, D.K. (1990) Food habits of bottlenose dolphins in the southeastern United States. Pages 309-328 in Leatherwood, S. and ReEves, R.R. (Eds) The Bottlenose Dolphin. San Diego, California, Academic Press, Inc.

BEARZI, M. (2005) Aspects of the ecology and behaviour of the bottlenose dolphins (Tursiops truncatus) in Santa Monica Bay, California. Journal of Cetacean Research Management 7(1): 75-83.

Bearzi, G., Politi, E. and Notarbartolo di Sciara, G. (1999). Diurnal behavior of free-ranging bottlenose dolphins in the Kvarneric (northern Adriatic Sea). Marine Mammal Science
15(4): 1065-1097.

Calliari, L.J. (1980) Aspectos sedimentológicos e ambientais da região sul da Lagoa dos Patos. M.Sc. Thesis. Fundação Universidade Federal do Rio Grande, RS, Brasil.

Campbell, G.S., Bilgre, B.A. and Defran, R.H. (2002) Bottlenose dolphins (Tursiops truncatus) in Turneffe Atoll, Belize: occurrence, site fidelity, group size and abundance. Aquatic Mammals 28: 170-180.

Castello, H.P. and Pinedo, M.C. (1977) Botos na Lagoa dos Patos. Natureza em Revista 2: 46-49.

Chao, L.H., Pereira, L.E. AND VIEIRA, J.P. (1985) Estuarine fish community of the dos Patos Lagoon, Brazil. A baseline study. Pages 429-450 in Fish Community Ecology in Estuaries and Coastal Lagoons: Towards an Ecosystem Integration. DR (R) UNAM Press, Mexico.

Cockсroft, V.G., AND Ross, G.J.B. (1990) Food and feeding of the Indian Ocean bottlenose dolphin off southern Natal, South Africa. Pages 295-308 in Leatherwood, S. and ReEves, R.R. (Eds) The bottlenose dolphin. Academic Press, San Diego, CA.

Cortese, N.A. (2000) Delineation of bottlenose dolphin populations in the western Atlantic Ocean using stable isotopes. M.Sc. Thesis, University of Virginia, $118 \mathrm{pp}$.

Costa, C.S.B., SEeliger, U. AND KINAS, P.G. (1988) The effect of wind velocity and direction on the salinity regime in the Patos Lagoon estuary. Ciência e Cultura 40: 909-912.

Cubero-Pardo, P. (2007) Distribution and environmental conditions related to the behavior in the bottlenose dolphin (Tursiops truncatus) and the spotted dolphin (Stenella attenuata) (Cetacea : Delphinidae) in Golfo Dulce, Costa Rica. Revista de Biologia Tropical 55: 549-557.

Dalla Rosa, L. (1999) Estimativa do tamanho da população de botos, Tursiops truncatus, do estuário da Lagoa dos Patos, RS, a partir da foto-identificação de indivíduos com marcas naturais e da aplicação de modelos de marcação-recaptura. M.Sc. Thesis, Fundação Universidade Federal do Rio Grande, Brasil. 104p. dos Santos, M.E. And Lacerda, M. (1987) Preliminary observations of the bottlenose dolphin (Tursiops truncatus) in the Sado estuary (Portugal). Aquatic Mammals 13(2): 65-80.

Duffield, D.A., Ridgway, S.H., And Cornell, L.H. (1983) Hematology distinguishes coastal and offshore forms of dolphins (Tursiops). Canadian Journal of Zoology 61: 930-933.

FERTL, D. (1994) Occurrence patterns and behavior of bottlenose dolphins (Tursiops truncatus) in the Galveston ship channel, Texas. Texas Academy of Science 46(4):299-317.

Flores, P.A.C. AND Fontoura, N.F. (2007) Ecology of marine tucuxi, Sotalia guianensis, and bottlenose dolphin, Tursiops truncatus, in Baia Norte, Santa Catarina state, southern Brazil. The Latin American Journal of Aquatic Mammals 5(2): 105-115.

Fruet, P.F. 2008. Abundância, mortalidade em atividades pesqueiras e viabilidade da população de botos, Tursiops truncatus, do estuário da Lagoa dos Patos, RS, Brasil. M.Sc. Thesis. Universidade Federal do Rio Grande, Brasil. 192p.

Garcia, A.M, VieIRA, J.P. AND Winemiller, K.O. (2001) Dynamics of the shallow-water fish assemblage of the Patos Lagoon estuary (Brazil) during cold and warm ENSO episodes. Journal of Fish Biology 59(5): 1218-1238. 
Garrison, L. And Yeung, C. (2001) Abundance Estimates for Atlantic Bottlenose Dolphin Stocks During Summer and Winter, 1995. NMFS/ SEFSC report prepared and reviewed for the Bottlenose Dolphin Take Reduction Team. Available from: NMFS-Southeast Fisheries Science Center, 75 Virginia Beach Dr., Miami, FL 33149.

Hansen, L.J. (1990) California coastal bottlenose dolphins. Pages 403-420 in Leatherwood, S. and Reeves, R.R. (Eds) The Bottlenose Dolphin. Academic Press, San Diego, California.

HARzen, S. (1998) Habitat use by the bottlenose dolphin (Tursiops truncatus) in the Sado estuary, Portugal. Aquatic Mammals 24(3): 117-128.

Hastie, G.D., Wilson, B. And Thompson, P.M. (2004) Fine-scale habitat selection by coastal bottlenose dolphins: application of a new land-based video-montage technique. Canadian Journal of Zoology 81: 469-478.

Hersh, S.L. AND Duffield, D.A. (1990) Distinction between Northwest Atlantic offshore bottlenose dolphins based on hemoglobin profile and morphometry. Pages 129-139 in Leatherwood, S. and Reeves, R.R. (Eds) The Bottlenose Dolphin. Academic Press, San Diego.

Irvine, A.B. Scott, M.D. Wells, R.S. And Kaufmann, J.H. (1981) Movements and activities of the Atlantic bottlenose dolphin, Tursiops truncatus, near Sarasota, Florida. Fishery Bulletin 79(4): 671-688.

KJERFVE, B. (1986) Comparative oceanography of coastal lagoons. Pages 63-81 in Wolfe, D.A. (Ed.). Estuarine variability. Academic Press, New York.

KrÜtZen, M., Sherwin, W.B., ConNor, R.C., Barré, L.M., DE Casteele, T.M., Mann, J. and Brooks, R. (2003) Contrasting relatedness patterns in bottlenose dolphins (Tursiops sp.) with different alliance strategies. Proceedings of the Royal Society of London Series B - Biological Sciences 270(1514): 497-502.

LEATHERWOOD, S. (1975) Some observations of feeding behavior of bottlenose dolphins (Tursiops truncatus) in the Northern Gulf of Mexico and (T. gilli) off southern California, Baja California, and Nayarit, Mexico. Marine Fisheries Review 37(9): 10-16.

LeatherWOOD, S., ReEVes, R.R. AND Foster, L. (1983a) The Sierra Club Handbook of Whales and Dolphins. San Francisco, Sierra Club Books. 302p.

Leatherwood, S. and Reeves, R.R. (1983b) Abundance of bottlenose dolphins in Corpus Christi Bay and Coastal Southern Texas. Contributions in Marine Science 26:179-199.

Lyamin, O., Pryaslova, J., Kosenko, P. and Siegel, J. (2007) Behavioral aspects of sleep in bottlenose dolphin mothers and their calves. Physiology \& Behavior 92: 725-733.

MANN, J. (1999) Behavioral sampling methods for cetaceans: A review and critique. Marine Mammal Science 15(1): 102-122

Mate, B.R., Rossbach, K.A., NieukiRk, S.L., Wells, R.S., Irvine, A.B., SCOTT, M.D. AND READ, A.J. (1995) Satellite-monitored movements and dive behavior of a bottlenosed dolphin (Tursiops truncatus) in Tampa Bay, Florida. Marine Mammal Science 11(4): 452-463.

McPhaden, M.J. (2004) Evolution of the 2002/03 El Niño. Bulletin of the American Meteorological Society 85: 677-695.

Mead, J.G. And Potter, C.W. (1990) Natural history of bottlenose dolphins along the Central Atlantic Coast of the
United States. Pages 165-195 in Leatherwood, S. and Reeves, R.R. (Eds) The Bottlenose Dolphin. San Diego, California, Academic Press.

MÖLLER, L.M. (1993) Observações sobre o comportamento e a ecologia do Boto, Tursiops truncatus, no Estuário da Lagoa dos Patos, RS, Brasil. Monografia de graduação, Fundação Universidade Federal do Rio Grande, Brasil, 32 p.

Möller, L.M., Simões-Lopes, P.C., Secchi, E.R. And Zerbini, A.N. 1994. Uso de fotoidentificação no estudo do deslocamento de botos, Tursiops truncatus (Cetacea, Delphinidae) na costa sul do Brasil. Proceedings of the 6th Meeting of South American Aquatic Mammals Specialists, Florianópolis, Santa Catarina, Brazil. p. 5-8.

Möller, L.M., Beheregaray, L.B., Allen, S.J. and Harcourt, R.G. (2006) Association patterns and kinship in female Indo-Pacific bottlenose dolphins (Tursiops aduncus) of southeastern Australia. Behavioral Ecology and Sociobiology 61: 109-117.

Möller, O.O. and Castaing, P. 1999. Hydrographical characteristics of the estuarine area of Patos Lagoon $\left(30^{\circ} \mathrm{S}\right.$, Brazil). Pages 83-100 in Perillo, G.M.E., Piccolo, M.C. AND PinO Quivira, M. (Eds) Estuaries of South America: Their Geomorphology and Dynamics. Springer-Verlag, Berlin.

Parsons, K.M., Durban, J.W., Claridge, D.E., Balcomb, K.C., Noble, L.R. And Thompson, P.M. (2003) Kinship as a basis for alliance formation between male bottlenose dolphins, Tursiops truncatus, in the Bahamas. Animal Behavior 66: 185-194.

Pinedo, M.C. (1982) Análise dos conteúdos estomacias de Pontoporia blainvillei (Gervais and D'Orbigny, 1844) e Tursiops gephyreus (Lahille, 1908) (Cetacea, Platanistidae e Delphinidae) na zona estuarial e costeira de Rio Grande, RS, Brasil. M.Sc. Thesis, Fundaçao Universidade do Rio Grande, RS, Brazil. 95pp.

Pryor, K. AND LindBerGH, J. (1990) A dolphin-human fishing cooperative in Brazil. Marine Mammal Science 6(1): 77-82.

RAmOS, L.A. AND VIEIRA, J.P. (2001) Composição específica e abundância de peixes de zonas rasas dos cinco estuários do Rio Grande do Sul, Brasil. Boletim do Instituto de Pesca, São Paulo, 27:109-121.

Read, A.J., Urian, K.W., Wilson, B. and Waples, D.M. (2003) Abundance of bottlenose dolphins in the bays, sounds, and estuaries of North Carolina. Marine Mammal Science 19(1): 59-73.

Rice, D.W. (1998) Marine mammals of the world - Systematics and distribution. Society of Marine Mammalogy. Special Publication No. 4.

SAAYMAn, G.S., TAYLER, C.K., AND BowER, D. (1973) Diurnal activity cycles in captive and free-ranging Indian Ocean bottlenose dolphins (Tursiops aduncus Ehrenburg). Behavior 44: 212-233.

SeEliger, U., Odebrecht, C. and CAStello, J.P. (1997) Subtropical convergence environments: the coast and sea in the southwestern Atlantic. Springer-Verlag, Berlim. 308pp.

ScotT, M.D. AND Chivers, S.J. (1990) Distribution and herd structure of bottlenose dolphins in the eastern tropical Pacific Ocean. Pages 387-402 in Leatherwood, S. and Reeves, R. R. (Eds) The Bottlenose Dolphin. San Diego, California, Academic Press.

Segura, I., Rocha-Olivares, A., Flores-Ramírez, S. and RojasBRACHO, L. (2006) Conservation implications of the genetic and ecological distinction of Tursiops truncatus ecotypes in the Gulf of California. Biological Conservation 133(3): 336-346. 
Shane, S.H. (1977) The population biology of the Atlantic bottlenose dolphin, Tursiops truncatus, in the Aransas Pass area of Texas. M.Sc. Thesis, Texas A\&M University, College Station, Texas. $239 \mathrm{pp}$.

SHANE, S.H. (1980) Occurrence, movements and distribution of bottlenose dolphin, Tursiops truncatus, in Southern Texas. Fishery Bulletin 78(3): 593-601.

Shane, S.H., Wells, R.S. and WÜrsig, B. (1986) Ecology, behavior and social organization of bottlenose dolphin: A Review. Marine Mammals Science 2(1): 34-63.

SHANE, S.H. (1990) Behavior and ecology of the bottlenose dolphin at Sanibel Island, Florida. Pages 245-265 in Leatherwood, S. and ReEves, R.R. (Eds) The Bottlenose Dolphin. San Diego, California, Academic Press.

SiMÕEs-Lopes, P.C. (1991) Ecologia comportamental do delfin, Tursiops truncatus (Montagu, 1821), durante as interações com a pesca artesanal de tainhas (Mugil spp) no sul do Brasil. Ph.D. Thesis, Pontifícia Universidade Católica, RS, Brasil, 199p.

Tagliani, P.R.A., Landazuri, H., Reis, E.G., Tagliani, C.R., Asmus, M.L. AND SÁNCHEZ-ArCiLlA, A. (2003) Integrated coastal zone management in the Patos Lagoon estuary: perspectives in context of developing country. Ocean \& Coastal Management 46: $807-822$.

TAYLER, C.K. AND SAAYMAn, G.S. (1972) The social organization and behavior of dolphins (Tursiops truncatus) and baboons
(Papio ursinus): Some comparisons and assessments. Annals of the Cape Provincial Museums (Natural History) 9(2): 11-49.

VieIRA, J.P. (2006) Ecological analogies between estuarine bottom trawl fish assemblages from Patos Lagoon, Rio Grande do Sul, Brazil and York River, Virginia, USA. Revista Brasileira de Zoologia 23(1): 234-247.

VIEIRA, J.P. AND SCAlabrin, C. (1991) Migração reprodutiva da Tainha (Mugil platanus Günther, 1880) no sul do Brasil. Atlântica 13(1): 131-141.

Wells, R.S., ScotT, M.D. And Irvine, A.B. (1987) The social structure of free-ranging bottlenose dolphins. Pages 247-305 in Genoways, H.H. (Ed.) Current Mammalogy, New York 1: 519p.

WeLLS, R.S. (1991) The role of long-term study in understanding the social structure of a bottlenose dolphin community. Pages 199-225 in PrYor, K. AND Norris, K. (Eds) Dolphin Societies Discoveries and Puzzles. University of California Press.

Wilson, B., Thompson, P.M. And Hammond, P.S. (1997) Habitat use by bottlenose dolphins: seasonal distribution and stratified movement patterns in the Moray Firth, Scotland. Journal of Applied Ecology 34: 1365-1374.

WÜRsIG, B. and WÜRsIG, M. (1979) Behavior and ecology of the bottlenose dolphin, Tursiops truncatus, in the South-Atlantic. Fishery Bulletin 77(2): 399-412.

ZAR, J.H. (1984) Biostatistical Analysis. Ed. Prentice Hall, Inc., New Jersey, USA. 
